\title{
Determinants of Chinese Direct Investment in Central-East Europe under the Belt and Road Initiative Framework: A Panel Data Analysis
}

Sicong Li

\author{
Department of Economics and Finance, Università Cattolica del Sacro Cuore, Milan, Italy
}

\begin{abstract}
The Chinese outward direct investment has experienced a dramatic growth worldwide under the Belt and Road Initiative (BRI) framework in the past few years, and naturally this growing Chinese capital also fosters the cooperation between Central East Europe (CEE) region and China. This research examines diversity of determinants holding impact on Chinese FDI flows from 2009 2018 in CEE region with implementation of panel data analysis, and our result partially explains what cause the heterogeneity concerning amount and density of Chinese capital in CEE countries. Our findings suggest us that generally countries with superior capacity in manufacturing sector and better performance in exportation are preferable capital destinations since Chinese investment is dominated by purposes like EU market access, relieving industrial overcapacity, industry upgrading, and a more effective integration of global industry chain. It is also illustrated in our findings that, from a macro perspective, it is intrinsic and inherent factors of individual economies and political concerns, rather than short-term financial factors, like financial market volatility, that could significantly determine the Chinese capital outflows in this region.
\end{abstract}

Keywords: Chinese outward direct investment, Central East Europe, The belt and road initiative, Panel data analysis

\section{Introduction}

Since 2013 Belt and Road Initiative (BRI) has been proposed by the Chinese government as an essential global development strategy for enhancing connectivity and cooperation among countries multilaterally in diverse fields. This ambitious strategy prompts Chinese investors to concentrate more on collaborations with partners in emerging economies like countries in Center-East Europe (CEE) for further business expansion. Besides, mass evacuation of capital from the EU and the US during the financial crisis also motivates CEE countries to find another reliable capital provider like China. In the past decades, China has benefited a lot from foreign direct investment (FDI) inflow. FDI flows into China has increased by more than two thousand times during 1981 2013, and it experienced a dramatic increase after 1991 (Parashar, 2015). FDI inflows stimulate Chinese firms to improve management and technology that was outdated in command economy age by accepting global competition and exploiting technology spillovers, especially in the manufacturing industry. As a consequence China achieved a successful economic growth due to its increasing productivity and export-oriented policy. While proposing the BRI in 2013 is recognised as a turning point for its global strategy both in economic and politic aspects. Throughout a series of joint projects, China exploits the BRI not only as a new channel to digest its surplus productivity, especially in steel and machinery industry, to explore appropriate investment destinations for its excessive capital, but also as a propagation for its political influence expansion. According to Statistical Bulletin of China's Outward Foreign Direct Investment (2019), published annually by China's ministry of commerce, China's FDI outward has increased by 53 times in flows, and 66.3 times in stock, during 2002 2018.

There exist several considerations for determining Chinese direct investment (Chinese FDI) destinations, including contributing country's development through natural resources explorations in other areas, and enhancing the global competitiveness of Chinese firms (Sauvent \& Chen, 2014). According to the eclectic theory (Dunning, 1981), three advantages, 
including ownership specific advantage, internalization advantage and location-specific advantage, are recognized as essential elements for engaging in FDI successfully. Also relevant articles indicate that FDI motivations are divided into four categories: market seeking, resource seeking, efficiency seeking, and asset seeking (Dunning \& Lundan, 2008). Concerning Chinese direct investment in CEE, some articles recognize that institutional factors and other less-quantifiable aspects, like market opportunities, EU membership, qualified but cheap labor, possibilities of acquiring visa or permit of residence, and quality of political relations, contribute as significant roles (Szunomar \& McCaleb, 2017). It is also confirmed in Szunomar's article that entering EU market, investment incentives, relatively low labor costs, skilled workforce, and market potential are attractive factors for Chinese investment in CEE region (Szunomar, 2018). Compared with motivations of Japanese direct investment in CEE region, it is found that there exist some similarities since both Chinese and Japanese firms are motived by low labor costs, low land costs, well-educated human resource in manufacturing industry, and access to EU market (Kawai, 2006).

According to statistical data published, from a broad perspective, Chinese direct investment in CEE region has increased from 436.66 million to 2.87 billion in period 2009 2018, that signifies it has $23.26 \%$ annual growth rate in average. Concerning export, machinery products, textile products, commodities and miscellaneous products are the three biggest categories, which occupy more than $50 \%$ of China's export to CEE countries (Liu \& Zhou, 2018). At the same time there exists heterogeneity concerning the density of Chinese direct investment (Chinese direct investment stock to GDP ratio) among CEE countries. For example, in this research, it is found that Belarus, Serbia, Romania, Bulgaria, Hungary, and Czech are countries with a relatively high density of Chinese direct investment stock, on the contrary, some countries like Latvia, Bosnia and Herzegovina have a low density of it. This heterogeneity is considered as a question requiring further research for explanations. Also, Liu and Zhou (2018) indicated that China's trade competitiveness index differs from one country to another. In the CEE region, China's export has relative more advantages in Czech and Poland while it has low competitiveness in Croatia, Lithuania, and Latvia. Despite of plenty of homogeneous among CEE countries, the existence of heterogeneity both in financial and political areas can be an obstacle for deepening cooperation between CEE and China, as there doesn't exist a single political and economic strategy for multilateral relationship development (Liu, 2013). Besides, asymmetric economy size of China and CEE countries may lead to unbalance and race to the bottom in bilateral trade, that requires CEE countries to institutionally coordinate together to gain competitiveness in scale and in efficiency (Liu, 2013).

The purpose of this research is mainly about analysis on determinants of Chinese direct investment in CEE region throughout incorporating country-level heterogeneity in diverse domains. This study of heterogeneity in CEE region suggests a quantified guidance to assist participants to reduce inefficient capital allocation and to avoid misleading decisions. Chinese direct investment is considered as an explicit indicator for business data analysis in concerned areas for future trend.

This research analyses the determinants of Chinese FDI amount and determinants of Chinese FDI to GDP ratio respectively, in diverse domains, based on panel data analysis. In this research, data that cover various areas - including market, financial factors, trade openness, industry structure, policies, and economic complexity - are used as variables in MLG model. As descripted above, heterogeneity among CEE countries is an essential factor for considerations about global strategy construction for Chinese capital. Ignoring heterogeneity may lead to unpredictable conflicts and mass of waste in capital resource. Further discussion followed about the effect of determinants in this paper is also based on significant parameters found in estimated models.

The rest of paper is organized as follows: In the second sector, diverse determinants of FDI found in previous literatures are introduced. In the third sector, data description, MGL model and its statistical test are presented as methods. Finally, in the fourth sector, discussions about economic aspects of results indicted by parameters from models are organized.

\section{Literature Review}


Since previous literatures particularly referring to Chinese outward FDI in CEE region are not abundant, this sector mainly introduces probable factors identified as determinants of FDI by previous literatures. Real cases and academic findings particularly referring to Chinese investment in the CEE region are installed separately as supplementary in the following. Empirically, FDI inflows into one country are thought to be dominated by explanatory variables from a diversity of categories: economic factors like market size, inflation rate, exchange rate, credit scale and monetary liquidity; intrinsic and inherent factors like industrial capability, technology, industrial structure, geographical superiority; certain institutional-political factors, and cultural factors, etc. (Tocar, 2018). In this article, explanatory factors from the following domains - market factors, financial factors, trade openness, industry structure, policies, and economic complexity - are selected, introduced, and examined as possible determinants.

\subsection{Market Factors}

Many articles support the assumption that market size and market potential ${ }^{1}$ are supposed to be significant determinants of FDI. Generally, market size and market potential indicators are supposed to have positive influence on FDI. That signifies higher GDP volume and higher GDP growth stimulate FDI to increase. Also, Bevan and Eastrin present the result that among transition economies, those countries that possessing larger economic scale are more attractive to FDI. Similarly, Resmini (2000) find CEE countries with larger population are more successful in attracting FDI in manufacturing. It is reasonable since a bigger market and rapid economic growth indicate more opportunities to exploit.

\subsection{Financial Factors}

Financial factors, here, consist of the inflation rate, real effective exchange rate, and domestic credit. Firstly let us start with the inflation rate. According to previous literature, high inflation rate is a sign of instability of internal economic in the host country, which further signifies incapability of government to balance its budget and failure of execution of appropriate monetary policy (Jean, 2002). Khan \& Mitra (2014) suggest the high inflation rate impairs economic activities, which leads to less FDI inflow. Singh \& Jena (2016) supplement the reason about this negative impact as high inflation rate raises the cost of import - including raw material and cost of capital - that adversely affect domestic and foreign demand.

Empirically, it is confirmed that weaker real effective exchange rate facilitates FDI as foreign capital might take advantages of relatively high purchasing power comparing to host countries (James, 2010). Froot \& Stein (1991) prove that inside imperfect capital market model, a weaker host currency increases FDI inward since the asset price tend to less expensive than that in home country. Adjei (2007) also prove that a strong currency could lead to cheap imports and expensive exports that will have negative influence on FDI, production, and even on unemployment rate in countries where they possess only elastic commodities' supplement.

As to domestic credit, Sane (2016) suggest that FDI inflow is positively influenced by the domestic credit to the private sector. While it is noted in their research that coefficient value is low (0.01) since the domestic savings are found to be low in analyzed countries that will directly determine their low domestic credit amount. Also, Cai, Gan \& Kim (2018) find sovereign credit ratings of recipient have a positive impact on FDI inflow while the ratings of donor countries have a negative impact.

\subsection{Trade Openness}

Here, in this research, openness is measured by export to GDP ratio and import to GDP ratio, since the proportion of trade to GDP usually defines the openness of a country. Resmini (2000) find inside CEE region, for manufacturing investment, high openness index increases most of vertical FDI inflows, especially in sectors where international trade flows in intermediate and capital goods are important. Singh \& Jun (1995) also indicate that exportoriented industrial structure is very important in attracting FDI. Similarly, Shafqat, Muhammad \& Abdul (2018), throughout the analysis about impact of openness on FDI of

\footnotetext{
${ }^{1}$ Here, market size is measure in terms of GDP, while market potential is measured in terms of annual GDP growth rate.
} 
selected four South Asian economies during 1981 2015, verify that openness has positive and significant effect on FDI.

\subsection{Industry Structure}

In this study, industry structure is indicated by three parameters: value-added in agriculture sector to GDP ratio, value-added in manufacturing sector to GDP ratio, and value-added in service sector to GDP ratio. According to previous research, industry structural factors and FDI inflow hold a mutual linkage between them. Throughout cross-sectional empirical analysis, Luo \& Tan (1997) provide a "structural attributes" model in their work and suggest industry structural factors have impact on market and financial performance in international production significantly, which leads to further influence on FDI. Conversely, through using the data of China's domestic industry from 2000 to 2009, Li \& Mou (2011) suggest FDI have an impact on both the development of the domestic industry and upgrade of industrial structure. Jiang \& Cheng (2017) also find that outward FDI may hold influence on adjustment of industrial structure through the industrial transfer effect, industry linkage and industrial competition effect.

\subsection{Policy}

When refer to study about Chinese direct investment in CEE countries, political factor here is composed of three fundamental and decisive policies: EU member, euro zone, and the $\mathrm{BRI}^{2}$. Without doubt, policies and political stability are supposed to affect FDI inflow in many aspects, entirely. Investors indicate in surveys that political and macroeconomic stability is considered as one of the key concerns (Walsh \& Yu, 2010). Root \& Ahmed (1979), Schneider \& Frey (1985), throughout study of aggregation of FDI inflows into developing economies in the late 1960s and slightly later time period, they find political instability affect FDI significantly. Nazeer \& Masih (2017) confirm that in Malaysia there exist co-integration between political instability and FDI and economic growth. Khan \& Akbar (2013) also perform evidences to imply political risk is a greater threat in low-and-middle-income countries comparing to the rest of the world.

\subsection{Economic Complexity}

Economic Complexity Index (ECI), originally proposed by Simoes \& Hidalgo (2011) at the MIT Media Lab, is a visual and quantified indicator measured by the composition of a country's productive output, to express the degree for economies about the multiplicity of useful knowledge embedded into it and to reflect the structures that emerge to hold and integrate knowledge. ECI contains observations from many aspects of economies, which help us to comprehensively capture the economies' competitiveness and their essence in global production chain. For example, Hartmann, Figueroa, Guevara \& Simoes (2016) verify that countries export more complex products tend to have low inequality in incomes. Balland, Figueroa, Petralia, Steijn, Rigby \& Hidalgo (2020) indicate that the spatial concentration of productive activities increases with their complexity, as complex economic activities concentrate disproportionately in a few large cities comparing to less-complex activities.

Incorporating this index into models is considered to be a novelty of this study, as few literatures refer to it as a core element for analysis about FDI. In comparison with industry structural parameters, ECI contains more accurate information about necessity and for each product, in each country, in international economic activities, individually. Simultaneously, in this research, value-added in high-middle-technology products to GDP ratio, in the manufacturing industry, is also observed as a parameter to verify the effect coming from ECI on FDI inflows.

\section{DATA AND METHODOLOGY}

\subsection{Data Description from a Macro Perspective}

Macro data description contains observations of explanatory variables and dependent variables. Apart from ECI, all data implemented in our research of explanatory variables are gathered from World Bank Open Data, involving data of 19 countries in Central-East Europe from 2008 2017. Data of Chinese FDI from 2009 to 2018 is collected from annual statistical reports published by Ministry of Commerce of PRC.

\footnotetext{
${ }^{2}$ Here political factors are expressed by dummy variables.
} 


\section{Sicong $\mathbf{L i}$}

Determinants of Chinese Direct Investment in Central-East Europe under the Belt and Road Initiative Framework: A Panel Data Analysis

According to annual statistical data published by Ministry of Commerce of PRC, total amount of Chinese FDI in CEE region increases linearly at approximate slope value 256.58 million/year, from 2009 2018, as shown in Figure 1 Figure 2 illustrates us the increment of Chinese FDI of individual countries in this period. We can find that Chinese investment has increased impressively in almost all CEE countries in recent years, and it has even experienced booming growth in certain countries like Belarus, Serbia, and Montenegro. Interestingly, our findings indicate that the heterogeneity among CEE countries appears significantly not only in Chinese FDI volume, but also in Chinese FDI/GDP ratio. In accordance with Figure $2 \mathrm{~b}$, it is observed that Chinese FDI/GDP ratio ranges between 1/1000 1/100 for most of CEE countries, while in Belarus and Montenegro this value reaches 1/10, which is much larger than that in Latvia. Besides, Figure 2 also presents us explicit heterogeneity in growth tendency of Chinese FDI in diverse CEE economies in recent years: in comparison to the rest of CEE countries, Chinese capital increases dramatically in countries like Belarus, Serbia, and Montenegro, both for FDI amount and FDI/GDP ratio. One of our objectives of this research is to explain the mechanism of formation about this heterogeneity inside CEE region throughout data analysis and discussions about determinants of Chinese FDI.

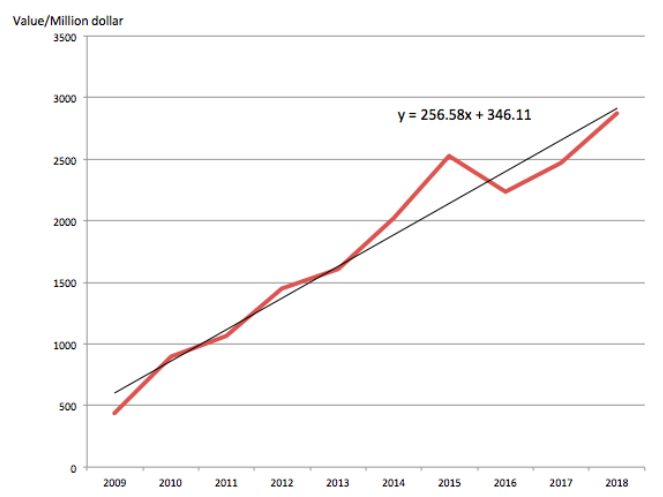

Figure 1: Annual data of the total amount of Chinese FDI in CEE countries

Source: Statistical Bulletin of China's Outward Foreign Direct Investment

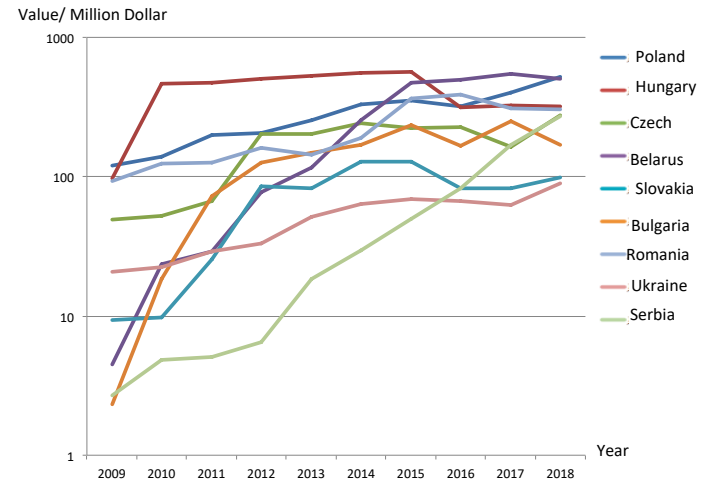

a. Chinese FDI stock in individual economies 


\section{Sicong $\mathrm{Li}$}

Determinants of Chinese Direct Investment in Central-East Europe under the Belt and Road Initiative Framework: A Panel Data Analysis

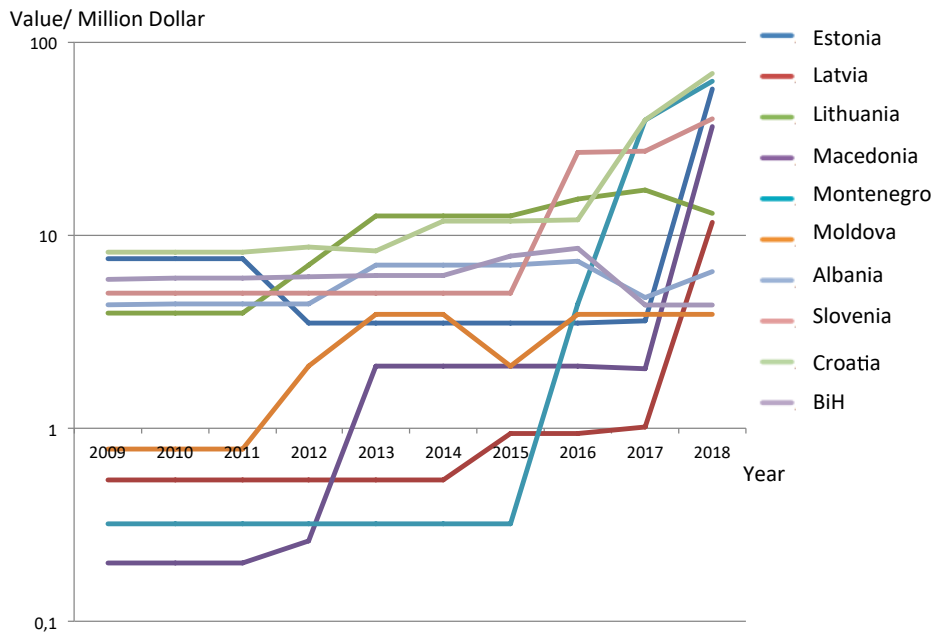

b. Chinese FDI/GDP ratio of individual economies
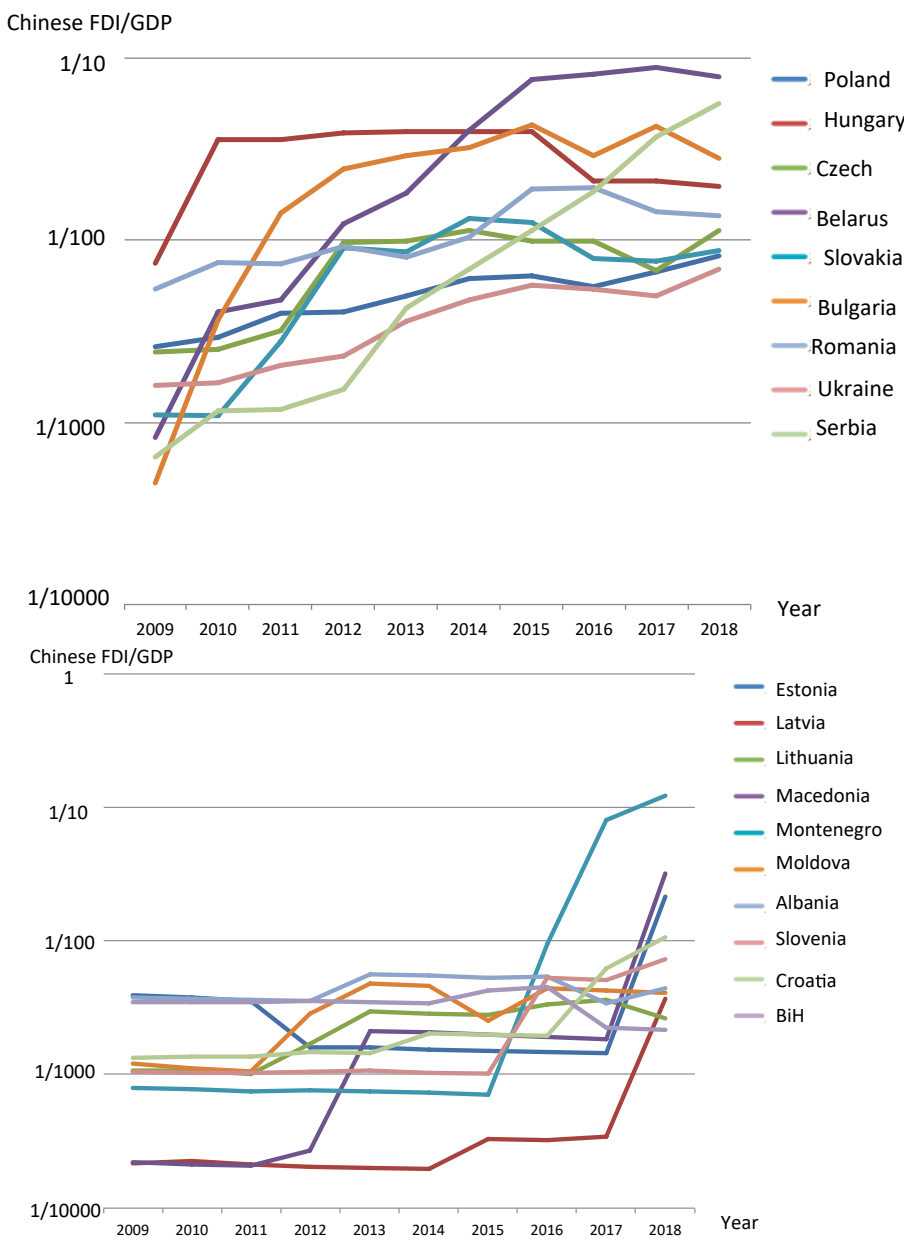

Figure 2: Annual data of Chinese FDI and FDI/GDP ratio in individual CEE economies

Source: Statistical Bulletin of China's Outward Foreign Direct Investment 


\section{Sicong $\mathrm{Li}$}

Determinants of Chinese Direct Investment in Central-East Europe under the Belt and Road Initiative Framework: A Panel Data Analysis

Our finding also implies that the Chinese FDI in diverse economies inside CEE region fits logarithmic linear distribution. Take 2017 year's data as an example, presented in Figure 3, Chinese FDI gathered in individual economies that ranked corresponding to ascending order ranges from 1.02 million (Latvia) to 548.41 million (Belarus), and increases linearly in logarithmic scale. In accordance with previous literatures, such logarithmic distribution is broadly found in certain parameters like FDI, GDP, and population of individual economies. Interestingly, here, logarithmic linear distribution is also observed in Chinese FDI/GDP ratio of individual economies in CEE region, when they are ranked as ascending order. Figure 3 presents data of Chinese FDI to GDP ratio of individual countries, in 2017, as an example. Figure 3 indicates us that logarithmic scale might explain this data distribution better, and Chinese FDI and Chinese FDI/GDP ratio are supposed to be logarithmized in data analysis so as to fit linear distribution better, since the original data verges on logarithmic normal distribution.

a. Ranking of Chinese FDI amount in 2017

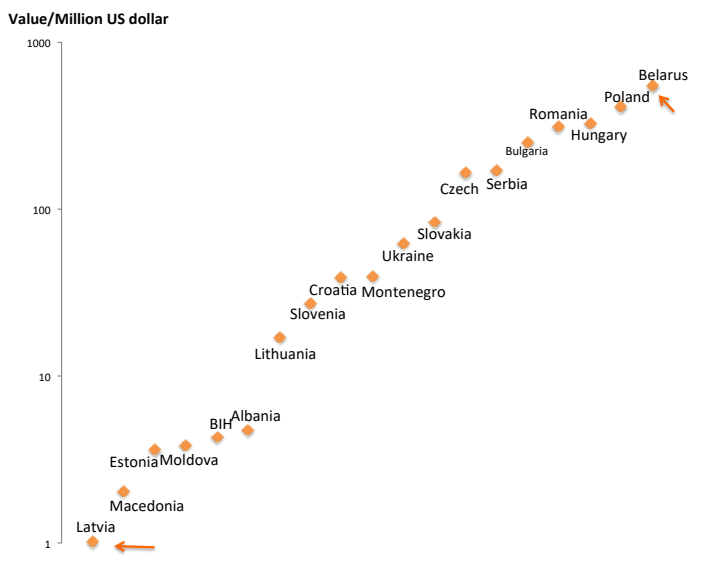

b. Ranking of Chinese FDI/GDP in 2017

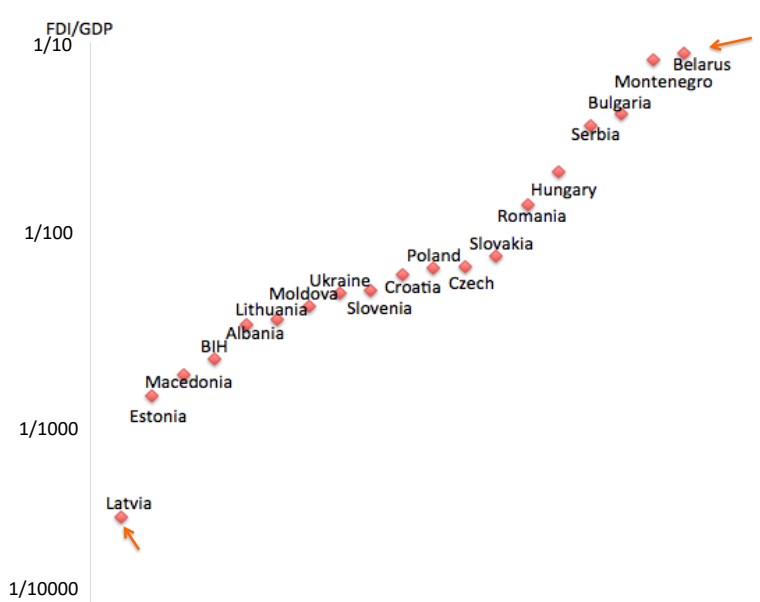

Figure 3: Chinese FDI amount ranking and FDI/GDP ratio ranking in CEE region in 2017

Source: Statistical Bulletin of China's Outward Foreign Direct Investment

In accordance with Figure 3, we could comprehend another elementary but essential issue: economies that possess more Chinese FDI might tend to have higher value in FDI/GDP ratio. However there is no rigid relationship between these two dependent variables - Poland is an exception. In 2017, Poland possesses the second largest share of Chinese FDI in the region, 
while it is ranked only the $9^{\text {th }}$ in Chinese FDI/GDP. The correlation between rankings found in FDI and FDI/GDP might be explained as FDI spatial aggregation in industry, which is confirmed by previous literatures, like Yang \& Zhao (2014) observe a significant impact of FDI spatial aggregation in study of automotive manufacturing industry in China.

\subsection{Methodology}

Given the finding that comparing to temporal volatility, the variance in explanatory variables is found to be much more significant in country-level, we assume that it is spatial diversity mainly dominates Chinese FDI outflows, and that is why in this research we pass the stationarity-detecting for factors. The empirical model we use for Chinese FDI amount is estimated as follow:

$$
\text { In } \mathrm{FDI}_{\mathrm{i}, \mathrm{t}}=\mathrm{a}_{0}+\sum_{j=1}^{n} \mathrm{a}_{\mathrm{j}} \mathrm{X}_{\mathrm{j}, \mathrm{i}, \mathrm{t}-1}+\varepsilon_{\mathrm{i}, \mathrm{t}}
$$

and the model for Chinese FDI to GDP ratio is similarly estimated as:

$$
\ln (F D I / G D P)_{i, t}=b_{0}+\sum_{j=1}^{n} b_{j} x_{j, i, t-1}+\varepsilon_{i, t}
$$

As presented in equations (3-1) and (3-2), $a_{0}$ and $b_{0}$ are constant numbers, $a_{1} \sim a_{j}$ and $b_{1}$ $\sim b_{j}$ show us the coefficient of each determinant. Three terms $(i, t, j)$ expresses the data of explanatory variable $j$ in country $i$ in time $t$. In order to avoid any confusion in causality between explanatory factors and dependent variables, one-year-lagged variable $X_{j, i, t-1}$ are implemented for all explanatory variables. The implementation of linear model is based on the assumption that a unit of increment in one explanatory variable 3 always holds the equal marginal effect on logarithmized value of dependent variable, and parameters $a_{1}, \ldots a_{i}$ are independent to each other.

Table 1: Explanatory variables holding impact on Chinese FDI or Chinese FDI/GDP

\begin{tabular}{|c|c}
\hline Explanatory Variable & Note \\
GDP & Ln (GDP of individual country) \\
INF & inflation ratio \\
EXP & export to GDP ratio \\
IMP & import to GDP ratio \\
DIF & difference between export to GDP ratio and import to GDP ratio \\
PPP & purchaing power parity \\
MANU & value added in manufacturing sector to GDP ratio \\
SER & value added in agriculture sector to GDP ratio \\
AGRI & value added in service sector to GDP ratio \\
MH & joing EU \\
EUDUM & joing euro \\
euroDUM & BRI strategy \\
BRIDUM & value added in high-middle technology products to GDP ratio \\
ECI & economic complexity index \\
\hline
\end{tabular}

Based on the results of $t$-value of each variable in regression ${ }^{4}$, factors that are verified as significant determinants for Chinese FDI are demonstrated in Table 1. And Chinese FDI amount (FDI) and Chinese FDI to GDP ratio (FDI/GDP) of individual CEE countries ${ }^{3}$ are selected here as two dependent variables. Finally in Table 1,14 explanatory variables including 3 political dummy variables - EUDUM, euroDUM, BRIDUM ${ }^{5}$ - are selected as significant determinants based on regression results. Since in Table 1 there exist only one factor - inflation ratio (INF) - closely correlated to short-term financial market volatility, it

\footnotetext{
${ }^{3} \mathrm{~A}$ unit of increment in GDP is defined by its logarithmized value.

${ }^{4}$ We also examined financial factors like exchange rate, domestic credit, M2 to GDP ratio in this research, while unfortunately we haven't observed any significant impact from them by t-test.

${ }^{5}$ Since the BRI is proposed in 2013, BRIDUM is set as 0 before 2013, and set as 1 from $2013 \sim 2017$ as a dummy variable.
} 


\section{Sicong $\mathrm{Li}$}

Determinants of Chinese Direct Investment in Central-East Europe under the Belt and Road Initiative Framework: A Panel Data Analysis

implies that in comparison of short-term financial factors, Chinese capital is more driven by some inherent and intrinsic factors involving individuals' economic and industrial structure, industrial capability, and certain political concerns.

\section{Empirical Results}

Table 2 assists us to illustrate an empirical overview about diversity of determinants covering different areas based on series of quantified coefficients. Obviously, two dependent variables - Chinese direct investment and Chinese direct investment to GDP ratio - are supposed to be affected by market factors, financial factors, trade openness, industry structure, policy, and complexity index, at different extend, which will be further discussed and analyzed in this sector from economic aspects.

Table 2: Results about coefficients of determinants

a. Results exclude Montenegro

\begin{tabular}{|c|c|c|c|c|c|c|}
\hline \multirow[b]{2}{*}{ Explanatory Variable } & \multicolumn{4}{|c|}{ FDI } & \multicolumn{2}{|c|}{ FDI/GDP } \\
\hline & Model 1 & Model 2 & Model 3 & Model 4 & Model 1 & Model 2 \\
\hline \multirow[t]{2}{*}{ GDP } & 0.51 & 0.57 & 0.73 & 0.75 & & \\
\hline & (4.57) & (4.64) & (6.18) & (6.68) & & \\
\hline \multirow{2}{*}{ INF } & & & & & $-0.02^{*}$ & $-0.03 * *$ \\
\hline & & & & & $(-1.91)$ & $(-2.48)$ \\
\hline \multirow{2}{*}{ EXP } & & $3.88^{* * * *}$ & 5.72 & 6.18 & & 4.65 \\
\hline & & (3.13) & $(4.76)$ & (5.49) & & (4.63) \\
\hline \multirow[t]{2}{*}{ IMP } & & $-4.53^{* * *}$ & -5.60 & -5.37 & & $-2.47^{* *}$ \\
\hline & & $(-3.32)$ & $(-4.08)$ & $(-4.13)$ & & $(-2.24)$ \\
\hline \multirow[t]{2}{*}{ DIF } & $3.72^{* * * *}$ & & & & $3.01 * * *$ & \\
\hline & $(3.00)$ & & & & $(2.68)$ & \\
\hline \multirow[t]{2}{*}{ PPP } & -4.81 & -5.55 & -4.20 & -3.41 & -3.89 & -3.51 \\
\hline & $(-5.12)$ & $(-6.24)$ & $(-6.13)$ & $(-3.56)$ & $(-4.43)$ & $(-4.03)$ \\
\hline \multirow[t]{2}{*}{ MANU } & $-11.02^{* * * *}$ & & $6.82 * *$ & & & \\
\hline & $(-2,65)$ & & (2.53) & & & \\
\hline \multirow[t]{2}{*}{ SER } & -18.78 & & & -9.57 & -7.52 & -9.53 \\
\hline & $(-4.81)$ & & & $(-5.30)$ & $(-4.11)$ & $(-5.39)$ \\
\hline \multirow[t]{2}{*}{ AGRI } & $-13.89^{* *}$ & & $10.28^{* * * *}$ & & & \\
\hline & $(-2,26)$ & & $(3.14)$ & & & \\
\hline \multirow[t]{2}{*}{ MH } & $3.77^{* * * *}$ & $4.54 * * *$ & & & $2.50^{* * *}$ & \\
\hline & $(3.04)$ & $(3.52)$ & & & (2.26) & \\
\hline \multirow[t]{2}{*}{ EUDUM } & $0.82^{* * * *}$ & & & & & \\
\hline & $(3.02)$ & & & & & \\
\hline \multirow[t]{2}{*}{ euroDUM } & $-0,94$ & $-0.94 * * *$ & -0.99 & -1.01 & $-0.57^{* *}$ & -0.97 \\
\hline & $(-4.05)$ & $(-3.44)$ & $(-3.67)$ & $(-3.92)$ & $(-2.61)$ & $(-4.14)$ \\
\hline \multirow[t]{2}{*}{ BRIDUM } & 0,66 & $0.48^{* *}$ & $0.55^{* * * *}$ & $0.64^{* * * *}$ & $0.53 * * *$ & $0.52^{* * * *}$ \\
\hline & (3.67) & (2.51) & $(2.85)$ & (3.44) & $(2.82)$ & $(2.81)$ \\
\hline \multirow{2}{*}{$\mathrm{ECI}$} & $0.72^{* *}$ & $0.81 * *$ & $1.12 * * *$ & $0.90^{* * * *}$ & $0.48^{*}$ & $0.62^{* * * *}$ \\
\hline & $(2.26)$ & (2.53) & $(3.42)$ & (3.09) & (1.77) & $(2.80)$ \\
\hline \multirow[t]{2}{*}{ CONS } & 18,91 & 6.92 & 4.78 & 10.93 & 8.90 & 9.38 \\
\hline & (6.16) & (7.72) & $(4.37)$ & (9.76) & (7.92) & (9.48) \\
\hline observations & 180 & 180 & 180 & 180 & 180 & 180 \\
\hline R-squared & 0.8047 & 0.7636 & 0.7657 & 0.7823 & 0.5500 & 0.5673 \\
\hline Adj R-squared & 0.7919 & 0.7525 & 0.7533 & 0.7721 & 0.5290 & 0.5470 \\
\hline
\end{tabular}

b. Results include Montenegro 
Sicong $\mathbf{L i}$

Determinants of Chinese Direct Investment in Central-East Europe under the Belt and Road Initiative Framework: A Panel Data Analysis

\begin{tabular}{|c|c|c|c|c|c|}
\hline \multirow[b]{2}{*}{ Explanatory Variable } & \multicolumn{4}{|c|}{ FDI } & \multirow{2}{*}{$\begin{array}{l}\text { FDI/GDP } \\
\text { Model } 1\end{array}$} \\
\hline & Model 1 & Model 2 & Model 3 & Model 4 & \\
\hline GDP & $\begin{array}{c}0.53 \\
(4.68)\end{array}$ & $\begin{array}{c}0.66 \\
(5.60)\end{array}$ & $\begin{array}{c}0,88 \\
(7.54)\end{array}$ & $\begin{array}{c}0.94 \\
(9.40)\end{array}$ & \\
\hline INF & & & & & $\begin{array}{l}-0.02 * * \\
(-2.00)\end{array}$ \\
\hline EXP & & $\begin{array}{c}3.43^{* * * *} \\
(2.88)\end{array}$ & $\begin{array}{c}4.89 \\
(4.04)\end{array}$ & $\begin{array}{c}6.21 \\
(5.70)\end{array}$ & $\begin{array}{c}5.29 \\
(6.80)\end{array}$ \\
\hline IMP & & $\begin{array}{c}-3.99 * * * \\
(-2.98)\end{array}$ & $\begin{array}{c}-4.34 * * * \\
(-3.09)\end{array}$ & $\begin{array}{c}-4.88 \\
(-3.64)\end{array}$ & $\begin{array}{c}-2.87 * * * \\
(-2.72)\end{array}$ \\
\hline DIF & $\begin{array}{c}3.70 * * * \\
(3.06)\end{array}$ & & & & \\
\hline PPP & $\begin{array}{c}-4.69 \\
(-5.24)\end{array}$ & $\begin{array}{c}-4.97 \\
(-5.98)\end{array}$ & $\begin{array}{c}-4.54 \\
(-5.23)\end{array}$ & $\begin{array}{c}-2.92 * * * \\
(-3.25)\end{array}$ & $\begin{array}{r}-3.34 \\
(-3.89)\end{array}$ \\
\hline MANU & $\begin{array}{l}-14.87 \\
(-3.78)\end{array}$ & & $\begin{array}{l}6.90 * \\
(2.59)\end{array}$ & & \\
\hline SER & $\begin{array}{l}-22.46 \\
(-5.75)\end{array}$ & & & $\begin{array}{c}-9.21 \\
(-4.75)\end{array}$ & $\begin{array}{r}-9.02 \\
(-4.72)\end{array}$ \\
\hline AGRI & $\begin{array}{l}-23.21 \\
(-4.03)\end{array}$ & & & & \\
\hline MH & $\begin{array}{c}5.27 \\
(4.38)\end{array}$ & $\begin{array}{c}6.30 \\
(5.08)\end{array}$ & & & \\
\hline EUDUM & $\begin{array}{l}0.71 * * \\
(2.48)\end{array}$ & & & & \\
\hline euroDUM & $\begin{array}{c}-0.70 * * * \\
(-3.08)\end{array}$ & $\begin{array}{l}-0.59 * * \\
(-2.31)\end{array}$ & $\begin{array}{l}-0.51^{*} \\
(0.061)\end{array}$ & $\begin{array}{l}-0.47 * \\
(-1.80)\end{array}$ & $\begin{array}{l}-0.55^{* *} \\
(-2.41)\end{array}$ \\
\hline BRIDUM & $\begin{array}{c}0.66^{* * * *} \\
(3.49)\end{array}$ & $\begin{array}{c}0.47 * * \\
(2.35)\end{array}$ & $\begin{array}{c}0.44 * * \\
(2.09)\end{array}$ & $\begin{array}{c}0.56 * * * \\
(2.75)\end{array}$ & $\begin{array}{c}0.45^{* *} \\
(2.25)\end{array}$ \\
\hline ECI & & & & & \\
\hline CONS & $\begin{array}{l}21.97 \\
(7.21)\end{array}$ & $\begin{array}{c}6.14 \\
(7.61)\end{array}$ & $\begin{array}{c}5.48 \\
(6.50)\end{array}$ & $\begin{array}{c}10.00 \\
8.21\end{array}$ & $\begin{array}{c}9.31 \\
(8.41)\end{array}$ \\
\hline observations & 190 & 190 & 190 & 190 & 190 \\
\hline R-squared & 0.7911 & 0.7504 & 0.7251 & 0.7464 & 0.4706 \\
\hline Adj R-squared & 0.7794 & 0.7408 & 0.7146 & 0.7367 & 0.4503 \\
\hline
\end{tabular}

Notes: Since ECI doesn't contain the data of Montenegro, results include Montenegro can only be observed throughout calculations with ECI being removed

Source: Author's calculation.

*Statistical significance at $10 \%$.

$* *$ Statistical significance at $5 \%$.

$* * *$ Statistical significance at $1 \%$

\subsection{GDP and GDP Growth}

Not surprisingly, in Table 2, it is found GDP has a significant impact on total volume of Chinese direct investment, this result suggests that despite of strict capital supervision and forceful government-oriented financial policy, nowadays, Chinese investment still follows the basic rules in FDI market inside CEE region and attempts to seek for profit margin in countries with high potential market. Kolstad \& Wiig (2012) also verify that Chinese outward FDI is attracted to large markets, especially to countries with abundant natural resource and poor 
institutions. However, surprisingly, GDP growth, here, isn't observed as an explanatory variable with significant impact on FDI or on FDI/GDP ratio. Despite many articles suggest that GDP growth is supposed to be a relevant factor for attracting FDI, some studies express that GDP growth might not necessarily have apparent relationship with FDI. For example, Liu \& Samantha (2017) indicate in their study, throughout data analysis for South Asian region, it is found that FDI is weakly and positively influenced by economic growth in Sri Lanka in the long term, since the economic growth in Sri Lanka is more correlated to its domestic investment rather than FDI. The weak correlation, inside CEE region, here, between economic growth and Chinese outward FDI, might be explained by the impact from forceful Chinese government-oriented policy on business strategy planning, which hinders many state-owned enterprises to be purely opportunistic in operating their capital. Another explanation for this weak relation between GDP growth and FDI is that the fluctuation of economic growth rate in some CEE countries is unpredictable and unstable in recent years after financial crisis. For example, during 2009 2017, Moldova achieved 9.004\% annual growth rate in GDP in 2013 year while it also experienced -6\% annual growth rate in 2009. Similarly, Estonia has experienced $7.442 \%$ annual growth rate in 2011 while its growth rate in 2009 is $-14.434 \%$. Given the fact that CEE countries might tend to be more sensitive and fragile to global or regional economic volatility due to their small economic scale and industrial structure, the entrance of Chinese investment into CEE market is more dominated by industrial structure integration, overseas market extension, and political corporation instead of financial speculation.

It is also found that, throughout data, Chinese capital not only concentrates on countries with higher GDP per habitant and superior industrial capacity in CEE region, like Czech, Poland, Hungary, but also attempts to explore opportunities in some so called 'periphery countries $^{\prime 6}$. For example, Bulgaria and Serbia, two Balkan countries, are not regarded as dominant powers in many aspects. Despite of uninspiring economic growth, dilapidated infrastructure, and lacklustre domestic market scale, these two countries are still attractive destinations for Chinese capital, as shown in Fig. 2 and Fig. 3. The high density of Chinese capital in Bulgaria and Serbia is more driven by political relationship and geographical intentions. The joint venture of Great Wall Motors and Litex in Bulgaria is an explicit case indicating how Chinese capital exploits the integration of the low-cost environment in Bulgaria with business extension in European car markets in a Western-dominated technology-intensive sector (Drahokoupil, Kirov, Muntean \& Radu, 2017). The profound SinoSerbia strategic partnership also prompts Chinese investment to follow the BRI strategy in Serbia. The construction of the first industrial park project in Serbia, financed by China, aims at attracting high-end talents and funds and offering jobs. One of the biggest telecommunication firms, Huawei, also announced a plan for building an innovation centre in Belgrade. These 'periphery countries' are almost excluded from the hegemonies inside Europe, even inside CEE region, but their geographic location, low labor-cost, and cultural similarity afford them the superiority for attracting FDI for accessing EU market. The same theory can also be implemented in Belarus and Romania similarly.

\subsection{Inflation}

We observe the impact from explanatory variable inflation ratio (INF) only in regressions of dependent variable FDI/GDP, as shown in Table 2. The result suggests us that the effect from INF on FDI/GDP is negative but not significant. In accordance with previous literatures, empirically, high inflation ratio is regarded as a symptom of instability and incapability in appropriate execution of monetary policy, which impairs the confidence and expectation of foreign investors. And this theory is also confirmed, here, to be accordant with our observations in CEE region. Just as the irrelevance of economic growth rate that we discussed above, similarly, this weak correlation between inflation ratio and density of Chinese capital in CEE region implies that Chinese investment is more dominated by farsighted political intentions instead of opportunism in short-term financial operations.

\footnotetext{
${ }^{6}$ This could be evidently observed from Figure 2 .
} 


\section{Sicong $\mathrm{Li}$}

Determinants of Chinese Direct Investment in Central-East Europe under the Belt and Road Initiative Framework: A Panel Data Analysis

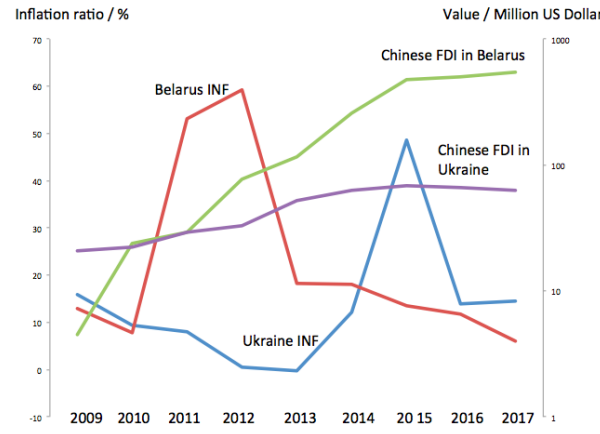

Figure 4. Annual data of inflation ratio and Chinese FDI in Belarus and Ukraine

Source: National Bureau of Statistics (for FDI) and World Bank (for inflation ratio)

In Figure 4, for example, we notice that the inflation ratio in Ukraine and Belarus fluctuates violently in recent years, FDI inward from China into these two countries, however, increases stably and apparently, particularly for Belarus where Chinese capital has increased by more than 100 times. Chen (2019) explains that Chinese capital surges in Belarus because of the establishment of China-Belarus Industrial Park, also called the Great Stone Industrial Park, in Minsk, and so far, this is the largest China-invested industrial park project overseas. Now this industrial park has attracted 26 leading Chinese firms including Huawei and China Merchants Group. These Chinese firms target at a broader and deeper EU market access throughout utilization of tax exemption and geographic superiority offered by Belarus. Besides, imitate and firm partnership between China and Belarus also induces booming growth in bilateral trade. Lukashenko, president of Belarus, stated in an interview that he is willing to see the acceleration of Chinese investment inflow into Belarus on a large scale since China has never any political strings attached and shows no interest in domestic politics, comparing to the Western countries (Nedzhvetskaya, 2011).

\subsection{Export and Import}

As shown in Table 2, it is verified in all regression results that export to GDP ratio has a significantly positive effect, and conversely, import to GDP ratio has a negative impact, on Chinese direct investment, and these two factors are approximately at equal absolute value in coefficient. In the second sector, according to previous study, we find that generally trade openness holds positive impact on FDI, while we ignore the discussion about individual effect coming from export share and import share. The difference between export and import (DIF) also affects FDI volume positively, which further indicates that countries with relatively larger export share and smaller import share are regarded as preferable destinations for Chinese capital.

Table 3. Ratio of exporting into (intra) EU / Total export of CEE countries

$\begin{array}{cccc}\text { Estonia } & 68 \%(2018) & \text { Serbia } & 66 \%(2018) \\ \text { Latvia } & 67 \%(2018) & \text { Macedonia } & 79 \%(2018) \\ \text { Lituania } & 59 \%(2018) & \text { Montenegro } & 48.4 \%(2018) \\ \text { Poland } & 80 \%(2018) & \text { Albania } & 76 \%(2018) \\ \text { Hungary } & 82 \%(2018) & \text { Romania } & 77 \%(2018) \\ \text { Czech } & 84 \%(2018) & \text { Bulgaria } & 69 \%(2018) \\ \text { Slovakia } & 85 \%(2018) & \text { Belarus } & 33 \%(2018) \\ \text { Slovenia } & 75 \%(2018) & \text { Ukraina } & 42.6 \%(2018) \\ \text { Croatia } & 68 \%(2018) & \text { Moldova } & 63.6 \%(2019) \\ \text { BIH } & 72.3 \%(2019) & & \end{array}$

Source: World Bank, except Macedonia, Montenegro, Belarus (from oec.world) 
Table 3 presents us the share of exportation into (intra) EU in total exportation of each CEE countries. Explicitly, this table suggests us that for most of CEE countries, EU market is their main export destination. Hence, the verification of positive effect of export and negative effect of import, here, indirectly supports our assumption that Chinese investment in CEE region is strongly motivated by purpose of EU market access throughout industrial structure integration instead of purely domestic market cultivation. Let us take Hungary - a country with high export ratio and high Chinese capital density - as an example: Manufacturing products related to machinery industry especially automobile manufacturing industry possess the largest portion in both export and import for Hungary. $82 \%$ of Hungarian exportation is intra-EU trade, and Germany is its most essential exporting destination. Besides, high export ratio is also an indicator to express good performance in trade balance of one country and might ease the government budget deficit caused by financial crisis, and might further promote the foreign capital's confidence. Just as what East Asian countries performed, a strategic export-oriented industry policy combined with authoritarianism induces the prominent economic growth (Stiglitz \& Yusuf, 2001).

\subsection{Industrial Structure}

The preference to particular industry area shown by the Chinese capital, could also be observed from three explanatory variables in industry structure sector: MANU, SER and AGRI. In Table 2 we find in the first column that these three explanatory variables all hold significantly negative impact on FDI. Apparently, this result doesn't contain any significance in economic aspects in real world since it can't provide any information about peculiarity of Chinese capital in industrial structure sector. We assume that it is over-fitting that causes negative impacts appearing in all industrial structure sectors, since we incorporate too many explanatory variables in the first column and computer might mistake the noise as an element, which makes us to fail to observe the inherent regularity inside some variables. In other columns, however, regression results suggest us that explanatory variable MANU and AGRI affect Chinese capital positively, while, explanatory variable SER, conversely, is observed as a negative factor for Chinese capital. This result verifies our assumption that Chinese investment concentrates, principally, on the manufacturing industry, and partly on primary industry, but with little emphasis on tertiary industry.

As a supplementary finding, it is found that in countries with larger Chinese investment or higher Chinese FDI density, like Hungary and Czech, machinery products tend to possess larger share in export structure. Countries without sufficient capacity in manufacturing productivity, like Bosnia and Herzegovina ${ }^{7}$, will rely more on exporting raw materials and labor-intensive products, and are less preferable to Chinese investment (oec.world). Instead of natural resource and low value-added labor-intensive industry, Chinese capital is more interested in structural integration and market value creation in high-middle tech industry and access to EU market with fewer barriers, throughout corporations with CEE countries.

Many cases also illustrate us the corporations in industry area between CEE countries and China. For example, Huta Stalowa Wola's construction equipment division, a firm has the longest tradition in Polish defense military, is acquired by China's Liudong Machineries with its distribution subsidiary, in 2012. And in 2013, China's Tri Ring Group Corporation acquires Polish Fabryka Lozysk Tocznych, which is the biggest Chinese investment in Poland (Szunomár, 2016). As to infrastructure filed, the China Overseas Engineering Group (COVEC) undertook a highway construction connecting Warsaw with Lódź. Góralczyk (2017) explains that the rapid expansion of Chinese capital in secondary industry is due to Chinese intentions of exploring an approach for relieving some of its overcapacity in manufacturing and capital. Meanwhile, neglect of the business opportunities in tertiary industry and heterogeneity in industrial sector proportion inside CEE region suggest us that, despite of the fact that currently the BRI strategies are restricted in particular areas, corporations in service industry might be regarded as a novel approach for Chinese capital to construct partnership and to excavate potential market in some countries without sufficient capacity in manufacturing sector but possessing superiority in tourism and relevant industry.

\subsection{EU and Euro}

\footnotetext{
${ }^{7}$ Natural resource, electricity, and products of textile industry compose the majority of export from Bosnia and Herzegovina
} 
Also, economic policies- expressed by two dummy variables: EUDUM and euroDUM - affect Chinese capital significantly. It is observed that the coefficient of EUDUM is in positive value while the coefficient of euroDUM is in negative value. The absolute value of coefficients suggests us that euro membership is the most significant political factor. The positive effect from EUDUM suggests that countries with EU membership are more attractive for Chinese capital as they are capable to provide assistance and convenience in EU market access. Conversely, the negative effect from euroDUM indicates us that, a unified currency - euromight be an obstacle for Chinese investors in further business expansion and flexible capital operation. Similar findings about fixed exchange rate and overvalued currency could also be found in research completed by Kiyota \& Urata (2004): throughout examining Japan's FDI by industries, they imply that even high volatility of exchange rate might discourage FDI, depreciation of the currency of the host country attracts FDI. It is also suggested that a stable and flexible exchange rate, instead of overvalued exchange rate, is more attractive to FDI. Sookia, Seetanah \& Moraghen (2015) analyzed the determinants of FDI in the case of Mauritius, and they confirm that overvaluation of the host currency as well as the volatility of exchange rate, affect FDI negatively, by the fact that deprecation of Mauritian Rupee fosters FDI inflow. In another emerging economy, Nigeria, it is also verified in a research that, deprecation of local currency, Naira, holds impact on FDI increase positively, and real FDI inflow are boosted by a stable and realistic exchange rate (Osinubi \& Amaghionyeodiwe, 2009).

Except euro membership, another explanatory variable - purchasing power parity (PPP) also influences Chinese investment negatively, indicating that Chinese investment in CEE region is motivated by relatively low labor-cost. This significantly negative impact of PPP partially proves that an overvalued currency, like euro, should be considered as a barrier for increment of FDI inflow in the host country, especially in labor-intensive industry. Unfortunately, in our study, we haven't directly observed any significant correlation between FDI and exchange rate in CEE region. However, evidently, we find the coherence in our results about correlation between effect from currency valuation on FDI and effect from price index on FDI, throughout analysis of diverse explanatory variables.

\subsection{ECI and Industrial Capacity}

Economic complexity index (ECI), an indicator expressing the essence and competitiveness of various economies in global production chain, is implemented as an explanatory variable in this research, combined with another explanatory variable $\mathrm{MH}$, to examine if Chinese capital is attracted by any economic factor in technical dimension. We observe that, here, ECI has a positive impact on Chinese investment significantly, and similarly, $\mathrm{MH}$ also affects Chinese investment positively. The positive impact coming from two explanatory variables $\mathrm{ECI}$ and $\mathrm{MH}$ strongly suggests that, Chinese capital is driven by the motivation of industrial structure integration with industrialized economies possessing relatively competitive productivity in high-middle-end industry.

As we discussed above, China intents to relieve its overcapacity in manufacturing productivity and capital throughout BRI strategy, and Chinese capital is attracted more by manufacturing industry that is capable to create high value-added products for exportation. Despite of relatively inferior economy and industry comparing to the Western Europe, some CEE countries possess the equal, even superior capability in investigation and technic implementation in particular industrial sectors (Hou, Liu \& He, 2018). For example, Czech, ranked in the top in ECI in CEE region, even higher than France in the list, is known for its cutting edge techniques in turboprops manufacturing and its superiority in automobile and light-aircraft industry, which can compete with that in Germany (Hou, Liu \& He, 2018). The reputation of global firms like Škoda and TOS also represents that Czech has a long history and abundant experience in industrialization and development in machinery industry. In accordance with statistic reports, the export from China to Czech is principally composed by machinery products, which possess more than $20 \%$ portion in Czech market, and base metal, and commodities (Liu \& Zhou, 2018). Apparently, the BRI strategy prompts and facilitates the bilateral corporation between Chinese firms and Czech firms. It is broadly observed that some Chinese technology companies, involving Changhong, Huawei, ZTE, have commenced to cultivate their business and technic corporation with Czech side. Besides, in some 'periphery countries', such as Serbia and Belarus, despite of insufficiency in industry, their relatively mature education system ensures these countries to have comparative superiority 
in labor resource for attracting FDI. This rich heritage in manufacturing industry and relatively low labor-cost in CEE region attracts China to exploit this multilateral corporation as a strategic breaking point for its industrial upgrading and EU market expansion.

\subsection{The BRI Strategy}

Last but not least, we find that dummy variable BRIDUM shows significantly positive effect on Chinese capital. This positive effect strongly proves that the BRI strategy, exactly, accelerates the Chinese investment in the CEE region. Empirically, the BRI strategic plan sets out five priorities, including reducing trade barriers, intensifying political co-ordination, deepening the integration in infrastructure of transportation, energy and information networks, developing more a robust financial cooperation, and encouraging a closer relationship and connections at sub-state level and societal level (Renwick, Gu, Gong, 2018). Trade and investment between CEE region and China are facilitated throughout approaches originated from these five priorities. The similar result is also found in a report done by World Bank (Soyres, Mulabdic, Murray, Rocha \& Ruta, 2018). Based on quantified data of shipment times estimated by Geographic information System and country-level trade costs generated from sectoral estimates of "value of time" by data of shipment times, their research expresses that shipment times and trade costs are significantly reduced by the BRI, especially for economies that participate the BRI projects. This article verifies that, for the BRI participants, the reduction of shipment times ranges from $1.7 \%$ to $3.2 \%$ and the reduction of trade costs ranges from $1.5 \%$ to $2.8 \%$. Also, this article highlights that it is policy reforms brought by the BRI that reduce the border delay and improve corridor management (Soyres, Mulabdic, Murray, Rocha \& Ruta, 2018).

In accordance with variety of cases, it is observed that generally the BRI strategy emphasizes more on increasing Chinese capital in infrastructure area and high-tech area. For example, a flagship project between CEE region and China - the cooperation in Hungary-Serbia Railway upgrading, connecting capitals between two countries with a design speed of $200 \mathrm{~km} / \mathrm{h}$ - is jointly announced by leaders from China, Hungary, and Serbia, in Bucharest in 2013. Huawei, a representative in high-tech telecommunication area, also operates its business in CEE region actively by creating its connection with local telecom operators and establishing its local supply center.

Electronic components and parts delivered from China are assembled in Hungary, and completed products are distributed to market in Europe, Center Asia and North Africa. In 2013, Huawei constructed its self-owned logistic center in Hungary to facilitate activities in purchasing, testing, producing, assembling and distribution, and to furnish a more efficient logistic system for overseas market (China Ministry of Commerce, 2019). Apart from China Railway and Huawei, other technology and manufacturing groups - like BYD, ZTE, and China General Technology (Group) - also attempt to expand their business operations in CEE region.

\section{CONCLUSION}

\subsection{General Conclusion}

With implementation of panel data analysis and MGL model, this research examines a diversity of determinants that might hold impact on Chinese outward FDI volume and its density in CEE region. At first, in the third sector we confirm a basic fact that in each CEE country the density of Chinese FDI principally follows its total amount, in logarithmic scale, which implies that agglomerative effectiveness affects outward Chinese FDI flows. Then, based on the findings and discussions presented in the fourth sector, we conclude that, from a macro perspective, it is intrinsic and inherent factors of individual economies and political concerns, rather than short-term financial factors, like financial market volatility, that determine the base of Chinese capital in this region significantly. Some intrinsic and inherent factors - which are not decided by temporary financial volatility - including market size (GDP), industrial structure (AGRI, MANU, SER), and technical capability (MH, ECI), are verified here, as significant determinants of Chinese capital. Composition of international trade (EXP, IMP, DIF), price index (PPP) might be partially affected financial volatility, however, they are also regarded as inherent and intrinsic factors here since these values are stable comparing to financial fluctuation and we haven't observed any evidence indicating that these explanatory variables follows other financial index. Results also suggest us that political factors (EUDUM, euroDUM, BRIDUM), represented by EU framework, euro membership and the BRI strategy, 
could exactly effect Chinese investment in this region: the BRI strategy and EU framework foster Chinese investment while euro membership hinders it. On the contrary, unfortunately, despite of multiple attempts, we haven't found any financial factor holding evident effect on Chinese investment. One exception is inflation ratio (INF). It is observed that the inflation ratio has a negative impact on Chinese FDI density (FDI/GDP) slightly. According to regression results and previous literatures, it is assumed here that, the Chinese investment flowing into CEE countries is generally dominated by motivation of industrial structure integration, overseas market extension, and political corporation, instead of financial speculation.

\subsection{Conclusions and Advice in Particular Field}

In aspect of industrial structure, our findings illustrate that Chinese capital prefers CEE economies with superior capacity in the manufacturing sector, especially in high-middle-end industry, because Chinese investors intend to exploit the geographic superiority in this region- integrated with relatively low cost and abundant experience in industrialization - for their overseas market expansion and upgrading in industrial structure. The fact that countries with higher export to GDP ratio and lower import to GDP ratio are found to be preferable destinations for Chinese capital also partially proves that China treats CEE countries as an intermediary for overseas market access and releasing its overcapacity in industrial productivity.

In terms of political factors, our results suggest that EU framework, indeed, attracts more Chinese FDI into CEE region, and this finding is also consistent with our hypothesis that EU market access is assumed as one of dominant intentions of Chinese investors. The negative effect observed from euro membership implies that a single currency with overvalued exchange rate might be an obstacle for further business cooperation due to less flexible capital operation. This finding is supported by another result that Chinese FDI is negatively correlated to purchasing power parity (PPP), which indicates that Chinese capital is sensitive to labor-cost and surely low labor-cost is more attractive. By the significantly positive impact from the BRI, we confirm that policy reforms introduced by this ambitious strategy throughout approaches like reduction of trade barriers and improvement of the efficiency in global logistic - exactly prompt Chinese investment, particularly for government-oriented projects, in some CEE economies, like cases observed in Belarus and Serbia.

Given the result that EU market access and industrial structure integration and upgrading are two principal motivations for Chinese investment entering into CEE region, we conceive that it is essential and necessary for governments and enterprises in CEE countries to excavate their comparative advantage in industry sector, and they are also supposed to offer convenience, facilitate procedures and optimize their business ecosystem for bilateral business operations in industrial area. Approaches like ameliorating logistic service for trade, easing restrictions in employment, and promising appropriate concession in taxation, could further cement economic and political partnership between China and CEE region. So far, we have observed many attempts both from China and CEE countries for ameliorations in this area, some articles, however, argue that a excessively intimate connection between China and some certain CEE countries might be regarded as a menace for EU cohesion, and might also threaten information security and induce reverse technology spillovers (Lucrezia, 2017; Amann \& Virmani, 2014). The security concern and the challenge for EU solidarity reminds us the necessity and the essence of creating an effective internal cooperation network inside CEE region and a more comprehensive integration covering all EU economies in order to possess substantial parity in business interaction with China.

As for Chinese investors, our findings indicate that Chinese capital has apparent partiality for manufacturing industry and industrialized economies with sufficient productivity and larger export capacity. On the one hand, this evident specific-industry-oriented policy contributes on forming a particular industry chain effectively in a short-term throughout substantial enhancement in productivity and management. On the other hand, excessive capital agglomeration on infrastructure and manufacturing might bring disequilibrium inside CEE region, since there exists heterogeneity in inherent properties among CEE economies and naturally some countries could not correspond the requirement for sufficient capability in specific industries. This apparent heterogeneity among CEE countries strongly suggests that it is necessary for Chinese investors to participate more in tertiary industry like tourism as 
novel approaches for their global business expansion. Besides, treating CEE region as a whole entity for strategic business development offers Chinese investors a greater potential to optimize their regional industry chain covering diverse industrial fields with a broader perspective. A more balanced distribution of Chinese capital inside CEE region with more transparent capital operations might not just partially ease the concerns and the suspicions from the Western world towards China, but also contributes on cultivating more business potentials in variety of fields for Chinese investors.

\subsection{Future Work}

It is supposed to indicate in the end that, without doubt, there remain quantities of tasks concerning this topic we need to complete in the future. First, we observe from the data that Chinese capital prefers certain economies with high export ratio, low import ratio, and superior capacity in manufacturing sector, and our findings explain it as the reflection of Chinese capital's specific purposes for industrial structure upgrading, comprehensive integration of global industry chain, and industrial overcapacity transferring, in certain areas, in CEE region, which are strategically planned by the BRI project. Meanwhile we haven't further studied what induces these inherent and intrinsic variances in industrial structure and industrial capacity among CEE countries from a systemic perspective. Second, we have noticed there is no significant correlation between Chinese outward FDI flowing into CEE region and any financial factor throughout multiple observations, and we empirically conclude that because Chinese capital is mainly dominated by long-term strategic intents rather than short-term financial speculation. However, we haven't discussed this phenomenon comprehensively from views of capital structure with specific cases, so we lack abundant and persuasive demonstrations for further explanation. Third, in this article we only demonstrate the determinants holding impact on FDI volume and FDI/GDP ratio, but we haven't referred to annual growth rate of Chinese FDI of individual country. Despite of inapplicability of financial factors here, a further study referring to annual growth rate of Chinese FDI might illustrate us how its growth rate fluctuates and whether its growth rate - not purely its total amount or FDI/GDP ratio - is affected by any financial factor. These tasks are expected to be finished in our future research.

\section{References}

- Adjei, A. (2007). Foreign Direct Investment and its Importance to the Economy of South Africa. Master thesis, University of South Africa.

- Agiomirgianakis, G., Asteriou, D., \& Papathoma, K. (2003). The Determinants of Foreign Direct Investment: A Panel Data Study for the OECD Countries. Discussion paper series, no. 03/06. Crossref

- Amann, E., \& Virmani, S. (2014). Foreign direct investment and reverse technology spillovers: The effect on total factor productivity. OECD Journal: Economic Studies, 2014, 129-153. Crossref

- Azam, P. (2002), Inflation and Macroeconomic Instability in Madagascar. African Development Review, 13(2), 175-201. Crossref

- Bah, O., Xie, K., Izuchukwu, O. (2015). Strategies and Determinants of Foreign Direct Investment (FDI) Attraction. International Journal of Management Science and Business Administration, 1(5), 81-89. Crossref

- Baldwain, R., Nino, V., Fontagné, L., Santis, A., \& Taglioni, D. (2008). Study on the Impact of the Euro on Trade and Foreign Direct Investment. Economic papers, 321. Crossref

- Balland, A., Figueroa, J., Petralila, G., Steijn. A., Rigby, L., \& Hidalgo, C. (2020). Complex economic activities concentrate in large cities. Nature Human Behaviour, 4, 248-254. Crossref

- Baltabaev, B. (2013). FDI and Total Factor Productivity Growth: New Macro Evidence. Monash University. Discussion Papers 27/13.

- Blonigen, A., \& Piger, J. (2011). Determinants of Foreign Direct Investment. NBER working paper series, no.16704. Crossref

- Cai, P., Gan, Q., \& Kim, S. (2018). Do Sovereign Credit Rating Matter for Foreign Direct Investment? Journal of International Financial Markets, Institutions and Money, 55, 5064. Crossref

- Drahokoupil, J., Kirov, V., Muntean, A., \& Radu, E. (2017). Chinese investment in Europe: corporate strategies and labour relations. Brussels: ETUI. 
- Dunning, J.H. \& Lundan, S.M. (2008). Multinational Enterprises and the Global Economy. 2nd ed. Reading : Addison-Wesley Publishing Company.

- ESCAP. (2017). A Study of ICT Connectivity for the Belt and Road Initiative (BRI): Enhancing the Collaboration in China-Central Asia Corridor. ESCAP working paper. United Nations ESCAP.

- Froot, A., \& Stein, C. (1991). Exchange Rates and Foreign Direct Investment : An Imperfect Capital Markets Approach. Quarterly Journal of Economics, 106(4), 1191-1217. Crossref

- Góralczyk, B. (2017). China's Interests in Central and Eastern Europe: Enter the Dragon. European View, 16(1), 153-162. Crossref

- Hartmann, D., Guevara, R., Figueroa, J., \& Simoes, A. (2016). Structural constraints of income inequality in Latin America. Integration \& Trade Journal, 40, 70-85.

- Hartmann, D., Guevara, R., Jara, C., Aristaran, M., Hidalgo, C. (2017). Linking Economic Complexity, Institutions and Income Inequality. World Development, 93, 75-93. Crossref

- Hou, Y., Liu, P., \& He, J. (2018). Challenges, Potential and advices for policy concerning cooperation with CEE countries under BRI framework. Beijing: Ministry of Commerce of the People's Republic of China. (in Chinese).

- Jamolovich, J. (2016). Most Common Potential Determinants of FDI: Review of Literature. International Journal of Innovation and Economic Development, 2(3), pp, 26-31. Crossref

- Jiang, S., \& Cheng, D. (2017). The Impact of Outward FDI on the Upgrading of China's Manufacturing Industry Structure: A Literature Review. International Journal of Economics and Finance, 9(6), 154-161. Crossref

- Kafait, A. (2018). The Determinants of Foreign Direct Investment in Service: A Case of South Asia and Southeast Asia. Journal of International Business Research, 17(1), 1-10.

- Khan, M. M., \& Akbar, M. I. (2013). The Impact of Political Risk on Foreign Direct Investment. (MPRA Paper No. 47283).https://mpra.ub.uni-muenchen.de/47283/ Crossref

- Khan, S., Ilyas, M, \& Chaudhary, R. (2018). Impact of Trade Openness and Inflation on Foreign Direct Investment: A Panel Data Analysis of Selected South Asian Countries. Retrieved June 20, 2020, from: https://www.researchgate.net/publication/337532421 Impact of Trade Openess and Inflation on Foreign Direct_Investment A Panel_Data_Analysis of Selected South_A sian Countries

- Khan, S., \& Mitra, P. (2014). A Causal Linkage between FDI Inflows with Select Macroeconomic Variables in India - An Econometric Analysis. IOSR Journal of Economics and Finance, 5(5), 2321-5933. Crossref

- Kiyota, K., Urata, S. (2004). Exchange Rate, Exchange Rate Volatility and Foreign Direct Investment. World Economy, 27(10), 1501-1536. Crossref

- Kolstad, I., \& Wiig, A. (2012). What determines Chinese outward FDI? Journal of World Business, 47(1), 26-34. Crossref

- Kornecki, L. (2011). FDI in central and eastern Europe: business environment and current FDI trends in Poland. Research in Business and Economics Journal, 3, 1-12.

- Li, X., \& Mou, L. (2011). Analysis of the Impact of FDI on the Upgrade of Industrial Structure in China's Domestic Industry. Journal of Jiangnan University, 10(5), 86-90.

- Lipsey, E. (2006). Measuring the Impact of FDI in Central and Europe. NBER working paper, no. 12808. Crossref

- Liu, H. \& Samantha, N. (2017). The Impact of FDI on the Economic Growth of Sri Lanka: An ARDL Approach to Co-integration. International Journal of Innovation and Economic Development, 5(5), 70-82. Crossref

- Liu, Y., Zhou, P., (2018). China-CEE Trade Indicators Research Report. (in Chinese).

- Liu, Z. (2013). Cooperation between China and CEE: Problems and solutions. CIIS. Retrieved June 19, 2020, from http://ciis.org.cn/gyzz/201309/30/content_6346139.htm/

- Lunn, J. (1980). Determinants of U.S Direct Investment in the E.E.C. European Economic Review, 13, 93-101. Crossref

- Luo, Y., \& Tan, J. (1997). How much does industry structure impact foreign direct investment in China? International Business Review, 6(4), 337-359. Crossref

- MaCaleb, A., \& Szunomar, A. (2017). Chinese foreign direct investment in central and eastern Europe : an institutional perspective, in Drahokoupil, J. (ed.) Chinese investment in Europe : corporate startegies and labour relations. European Trade Union Institute, Brussels, 121-140. 
- Mistura, F., \& Roulet, C. (2019). The determinants of Foreign Direct Investment: Do statutory restrictions matter? OECD working papers on International Investment 2019/01.

- Mottaleb, K., \& Kalirajan, K. (2010). Determinants of Foreign Direct Investment in Developing Countries: A Comparative Analysis. ASARC working paper 2010/13. Crossref

- National Bureau of Statistics. (2018). 2017 Statistical Bulletin of China's Outward Foreign Direct Investment. Beijing: Ministry of Commerce of the People's Republic of China.

- National Bureau of Statistics. (2019). 2018 Statistical Bulletin of China's Outward Foreign Direct Investment. Beijing: Ministry of Commerce of the People's Republic of China.

- Nazeer, A. M., \& Masih, M. (2017). Impact of political instability on foreign direct investment and Economic Growth: Evidence from Malaysia. (MPRA Paper No. 79418). https://mpra.ub.uni-muenchen.de/79418/

- Nedzhvetskaya, N. (2011). China and Belarus: A Special Relationshi. Harvard Political Review. Retrieved June 22, 2020, from https://harvardpolitics.com/world/china-andbelarus-a-special-relationship/

- Osinubi, T., \& Amaghionyeodiwe, L. (2009). Foreign Direct Investment and Exchange Rate Volatility in Nigeria. International Journal of Applied Econometrics and Quantitative Studies, 6(2), 83-116.

- Pan, Y. (2003). The inflow of foreign direct investment to China: the impact of countryspecific factors. Journal of Business Research, 56, 829-833. Crossref

- Parashar, S. (2015). Factors affecting FDI inflow in China and India.

- Pavlinek, P. (1998). Foreign Direct Investment in the Czech Republic. The Professional Geographer, 50(1), 71-85. Crossref

- Renwick, N., Gu, J., \& Gong, S. (2018). The impact of BRI investment in infrastructure on achieving the Sustainable Development Goals. K4D Emerging Issues Report. Brighton, UK: Institute of Development Studies.

- Resmini, L. (2000). The Determinants of Foreign Direct Investment in the CEECs : New evidence from sectoral patterns. The Economics of Transition, The European Bank for Reconstruction and Development, 80(3), 665-689. Crossref

- Root, R., \& Ahmed, A. (1979). Empirical Determinants of Manufacturing Direct Foreign Investment in Developing Countries. Economic Development and Cultural Change, 27(4), 751-767. Crossref

- Saaed, J., \& Hussain, A. (2015). Impact of Exports and Imports on economic Growth: Evidence from Tunisia. Journal of Emerging Trends in Economics and Management Science, 6(1), 13-21.

- Sane, M. (2016), Determinants of Foreign Direct Investment Inflows to ECOWAS Member Countries: Panel Data Modeling and Estimation. Modern Economy, 7, 1517-1542. Crossref

- Sanfey, P., \& Zeh, S. (2012). Making sense of competitiveness indicators in south-eastern Europe. European Bank for Reconstruction and Development working paper, no. 145.

- Sauvant, P., Chen, Z., (2014). China's regulatory Framework for Outward Foreign Direct Investment. China Economic Journal, 7(1), 141-163. Crossref

- Schneider, F., \& Frey, F. (1985). Economic and Political Determinants of Foreign Direct Investment. World Development, 13, 161-175. Crossref

- Shahriar, S., Kea, S., \& Qian, L. (2019). Determinants of China's outward foreign direct investment in the Belt \& Road economies: A gravity model approach. International Journal of Emerging Markets, 15(3), 427-445. Crossref

- Simoes, A., \& Hidalgo, C. (2011). The Economic Compelxity Observatory: An Analytical Tool for Understanding the Dynamics of Economic Development. Workshops at TwentyFifth AAAI Conference on Artificial Intelligence. San Francisco: 2011 AAAI Workshop.

- Singh, A., \& Jena, A. (2016). Impact of inflation rate on the inflow of foreign direct investment in India [online]. Project Guru. Retrieved June 21, 2020, from https://www. projectguru.in/inflation-rate-impact-foreign-direct-investment

- SINOIMEX. (2018). Big Data Report on Trade Cooperation under the Belt and Road Initiative.

- Sookia, N., Seetanah, B., \& Moraghen, P. (2015). Impact of Exchange Rate and Exchange Rate Volatility on Foreign Direct Investment (FDI) Inflow for Mauritius: A Dynamic Series Approach. Western Turtle Bay resort: $5^{\text {th }}$ Annual Conference African Accounting and Finance Association.

- Soyres, F., Mulabdic, A., Murray, S., Rocha, N., \& Ruta, M. (2018). How Much Will the Belt and Road Initiative Reduce Trade Costs? Policy Research Working Papers, no. 8614. 


\section{Sicong $\mathrm{Li}$}

Determinants of Chinese Direct Investment in Central-East Europe under the Belt and Road Initiative Framework: A Panel Data Analysis

- Štrach, P., \& Everett, M. (2006). Japanese Foreign Direct Investment in the Czech Republic: A Motivational Analysis. Problems and Perspectives in Management, 2006(1), 22-31.

- Stiglitz, J., \& Yusuf, S. (2001). Rethinking the East Asian Miracle. New York: Oxford University Press. Crossref

- Szunomár, A. (2016). Chinese investment in central and Eastern Europe [online]. Sylff Association. Retrieved June 22, 2020, from https://www.sylff.org/news_voices/16859/

- Szunomár, Á. (2018). Chinese FDI in Central and Eastern Europe. An Overview of Factors Motivating Chinese MNES in the CEE Region. Global Economic Observer, 6(2), 4-16.

- Tocar, S. (2018). Determinants of Foreign Direct Investment: A Review. Review of Economic and Business Studies. 11(1), 165-196. Crossref

- Tülüce, S., \& Dogan, I. (2014). The Impact of Foreign Direct Investments on SMEs' Developmet. Procedia-Social and Behavioral Sciences, 150, 107-115. Crossref

- Walsh, P., \& Yu, J. (2010). Determinants of Foreign Direct Investment: A Sectoral and Institutional Approach. IMF working paper, WP/10/187. Crossref

- Yang, Y., \& Zhao, G. (2010). Spatial Aggregation, FDI Spillover and the Development of China's Automotive Manufacturing Industry - Based on Spatial Panel Data from 2003 to 2008. Research for Economics and Management, 2014(4), 91-98. 